\title{
First Responders While Administering Unrealized Integrated Pre-Hospital
}

\author{
Fitri Anita ${ }^{1}$, Tita Hariyanti ${ }^{2}$, Tony Suharsono ${ }^{3}$ \\ ${ }^{1}$ Master Program of Nursing, Faculty of Medicine, Universitas Brawijaya, Indonesia \\ ${ }^{2}$ Master Program of Hospital Management, Faculty of Medicine, Universitas Brawijaya, \\ Indonesia \\ ${ }^{3}$ Department of Emergency Nursing, Faculty of Medicine, Universitas Brawijaya, Indonesia \\ Email: fitri.anita@gmail.com
}

\begin{abstract}
The mortality rate concerning post-traffic accident trauma is estimated to gets higher for the next years. When a traffic accident occurs, the provision of first aid is carried out by laypeople/communities around the scene with limited knowledge and equipment available. Especially, if a traffic accident occurs in an area that has not applied an integrated prehospital service. This research aims to explore the first responders' care administration in a region that has not applied pre-hospitalized emergency service formally. This is a qualitative study with a case study approach. This approach is chosen to identify emerging themes. The research was conducted in Konawe municipality, from February until March 2020. It was done by interviewing 8 participants consisting of the citizens, traffic police officers, hospital party, and health agency in the research site that had been selected based on the applied inclusion criteria. Five themes were found in this research. First responders struggle to save the traffic accident victims after the incident. They helped accident victims with limited tools. They helped the accident victims by sending them off to a health service immediately. They attempt to help the victims by sending them off to health services by using public transportation. Support Police action when finding accident victims. It could be concluded that in the area that has not applied integrated-emergency pre-hospital service would directly influence service availability in the society. The people would struggle to substitute the roles of medical workers in administering the first aid outside of a hospital with various limitations. Education and training programs concerning administering first aid, given quarterly, could be an appropriate health service program to offer for broader people as the first responders.
\end{abstract}

Keywords: First Responder, Pre-Hospital Care, Traffic Accident.

\section{A. INTRODUCTION}

Traffic accidents become serious problems to cause trauma (Goonewardene, Baloch, Porter, Sargeant, \& Punchihewa, 2010). In 2030, it is predicted that the traffic accident rate will be in the fifth rank as the main cause of worldwide mortality. This traffic accident is $90 \%$ predicted to occur in low and moderate-income countries in which traffic accident becomes the mortality cause for both adolescents and children (Debenham, Fuller, Stewart, \& Price, 2017; Mock, Tiska, Adu-Ampofo, \& Boakye, 2002; Wesson, Boikhutso, Bachani, Hofman, \& Hyder, 2014). In Indonesia, according to the Indonesian police traffic corp data, it is found that there are 3 death victims per hour due to traffic accidents (Polri, 2018). This high mortality rate due to traffic accident impacts the increasing rate of mortality and disability. Thus, there is a need for an immediate effort to provide pre-hospital service (Elmqvist, Brunt, Fridlund, \& Ekebergh, 2010). 
The mortality rate concerning post-traffic accident trauma is estimated to gets higher for the next years. It is possible due to higher income and economy so that there will be a tendency to own a vehicle. Thus, it influences the increasing volume of vehicles on the road. It will be much worst with such current conditions in a country that could not develop better infrastructure and create the required system for the sake of traumatic victims' safety. This situation will influence the low and moderate-income countries that do not have formal trauma services because they cannot fulfill the people's necessity for dealing with health service (Debenham et al., 2017).

A good quality toward pre-hospital services of trauma cases is required to decrease mortality and disability rates due to trauma. Mortality due to trauma is predicted higher in a developing country since it only has a very basic integrated Emergency State Prevention system or it could even have no such system (Debenham et al., 2017; Husum, Gilbert, Wisborg, Van Heng, \& Murad, 2003). In a developing country, $40 \%-50 \%$ of mortality cases could occur because of trauma, and most of them are occurred outside of hospitals (Debenham et al., 2017; Mock, Jurkovich, Arreola-Risa, \& Maier, 1998). This increasing traffic accident becomes the priority to provide health necessity for the people by improving the emergency prehospital service system. It has been proven that an integrated emergency state service system could reduce the influences of mortality and disability from traumatic accidents (Wesson \& Kwong, 2017).

The more organized pre-hospital service system causes communication to be more coordinated for both among the concerning caregiver institutions. Activating emergency communication services will be executed by the nearest person group on the spot (Kironji et al., 2018). However, the engaged challenges cause the emergency service of pre-hospital in developing and low-income countries have not been promoted optimally or event they do not exist.

Pre-hospital care is a set of treatments on the spot until the injured victims are sent off the hospital (Pallavisarji, Gururaj, \& Girish, 2013). The aid administration in the pre-hospital phase is expected to be applicable quickly and accurately by the professionals (Beuran et al., 2012). The facts in some regions are when traffic incidents occur, those who administer the firs aid (first responder) are not the trained medical professionals but instead common people or surrounding citizens near to the incident location (Khorasani-Zavareh et al., 2009). Common people become the first responders that run into emergencies. They provide the first aid for the victims. Thus, they are called first responders (Pigoga, Cunningham, Kafwamfwa, \& Wallis, 2017). The referred common people are such as family members, community leaders, motorbike riders, public transportation drivers, and the police officer (Balikuddembe, Ardalan, Khorasani, Nejati, \& Raza, 2017).

Several patterns of aids could be given for the people in pre-hospital service. Acting slowly in selecting the best action to catch the suspect, to drag the victim out of the vehicle without having sufficient supporting devices, to stop and close the injuries, to immobilize the broken limbs with the cut trunks, to regulate the traffic 
flows, and to prioritize the care administration for the injured victims that to take care of the already death victims (Chokotho et al., 2017). Besides that, the traffic accident victims are directly sent off by the surrounding people or the family to the hospital. They do it with their private vehicles or public transportation without first aid (Novitaria, Wigati, \& Sriatmi, 2017). Based on the facts, several things make the researchers interested to explore the care administration for trauma victims due to traffic accidents in regions that have not applied pre-hospital service formally.

\section{B. METHOD}

This is a qualitative research method. A qualitative research method is a research conducted in a natural setting of the object conditions by applying interpretative and naturalistic paradigms to the research focus. The applied approach to this research is a study case approach. A study case is research that has multi-perspective analysis nature. It means the researcher does not only observe the experience and perspective of the participant but also explores the experiences from various-different and relevant perspectives that have interactions among them. This qualitative research design with a study case approach is seen as appropriate to be carried out because it describes the experiences of administering pre-hospital care for traffic accident victims in a comprehensive manner. It is due to the existence of the experience descriptions from various relevant parties, such as common people, police officers, hospitals, and health agencies.

This research was done for the citizens, traffic unit officers, hospital workers, and health agency staffs in Konawe municipality. The participant selection participants were the purposive sampling technique. It involves the participant with certain research criteria so the obtained data will be consistent with the investigated topics. The numbers of the participated participants in this research are 8 persons with the determined inclusion criteria. The criteria deal with emergency care administration outside of the hospital.

This research was conducted in Konawe Municipality. The time and place to promote the interview were adjusted with the targeted purposes in this qualitative research. The researchers and the informants agreed on the places based on where the informants were at that time. The interview with the informants was done after meeting the time and place agreements for the sake of comfortability and privacy of the informants. This research was carried out from February until March 2020. The subjects of the research consisted of common people, police officers, hospital officers, and health agency officers.

The applied data collection procedures are in-depth interview techniques and observation. The applied in-depth interview uses open and semi-structured questions. The applied interview explored the participants' experience deeper and it was expected to elicit new experiences about what the participants felt. Before promoting the interview process, the researchers initially prepared several question keys as the interview guidelines. It was done to facilitate the researchers carrying out the interview and collect consistent data. 
The interview process was conducted for the participant. It was then recorded by using a voice recorder of the researcher. It was OPPO A9, 2020, smartphone. Dealing with the non-verbal reaction of the informant and the atmosphere during the interview were written by the researchers on a field note. All recordings were then transferred to a computer and analyzed.

\section{RESULT AND DISCUSSION}

\section{First Responders Struggled to Secure the Traffic Accident Victim's Position After the Incident}

The occurring accident is caused by an interaction between vehicles that could make the victims in various poor posture positions. The victims could have been dragged in by the vehicles, fallen, or sprawl on the road. It is as stated by this participant:

"His position was sprawling on the asphalt, right in the middle" The motorbike was dragged in. Thus, it was a bit farther from the house. It meant he was dragged into the edge of the pedestrian" (P6).

Based on this condition, in several accident cases, the first responders arrived on the spot and attempted to secure the victim's position. When the common people see a traffic accident, they would go directly to the spot the find out the victim's condition. Generally, the first responders cooperated in transporting the victims to a safe place. They took the victims to the side of the roads or the nearest houses of the surrounding people as stated by this participant:

"After the accident, the people directly took the victim to my house. They lifted the victims (showing the action) instead of carrying the victims. I meant the victim was lifted while standing up. One of them could be carried but the other should be given a ride and carried. You know one of them had been lifted? I do not know how to call it, you know? He was lifted. The point is he was lifted and could not stand any more" (P6).

"If there were such victims, the most important is to check them, then helping them by moving them outside from the road and to check his condition" (P6).

The other participant also expressed the same thing that the first aid they did was moving the victims to the side of the road: "Then, when it was getting closer, outside of the gate,

I saw AS was carried. 3 people were carrying him and took him from the spot as he was on the side of the road instead of the pedestrian. So, those three people held him up under a tamarind tree near the pedestrian. Then, AS was laid down on the pedestrian while he was still wearing a helmet (it was less conducive due to sounds of motors' engines). He was wearing all of his attributes, his shoes, and even his backpack" (P3).

"Back then, on the day, the victim was carried from the road to the side of the pedestrian. Yup, it is. When the accident occurred, we carried him from the middle of the road to the side of a pedestrian" (P8). 
The utterances from the participants showed that the victim's position was not good during the accident occurred. It made the first responders struggled hard to provide the first care for the victim. An accident due to a vehicle crash on the road could drag the victims for several meters. They could even fall and sprawl in the middle of the road. To engage in several conditions, the first responders cooperated with other people to move the victim to a safer place based on the spot. By carrying the victim to the nearest house became the first aid they could provide for the victim. All given actions by the first responders were done to make the victim safer. Thus, further care could be immediately administered.

When an accident occurred, first responders on the spot would respond to provide the aid. An accident due to a vehicle crash on the road could drag the victim several meters away. They could even fall and sprawl in the middle of the road. To engage in several conditions, the first responders cooperated with other people to move the victim to a safer place based on the spot. They moved the victims to the side of the road or the nearest house of the surrounding people. Those were the first aids they could provide for the victims. It had a purpose to make them safe so further aid could be immediately administered.

Similar findings were in line with the previous findings. They found that calling the emergency service, extinguishing the fire, and taking victims from the accident spot (to prevent a further accident, to prevent any danger for the rescuer or observer, to control the crowd, and to provide first aid) became the preferred actions conducted by the first responders while they were on the spot (Jayaraman et al., 2009a).Another study found $13.8 \%$ of people admitted one of the most frequent actions to provide while taking care of a traffic accident victim was securing the victim and the rescuer (Pallavisarji et al., 2013).

\section{First Responders Struggled to Help the Accident Victims with their Limited Tools.}

The first responders struggled to provide the care during the accident with its limited tools. The participants stated that during the accident, they picked anything they could to take care of the victims. The participants did not have the required tools to promote the first aid of emergency conditions, such as when it dealt with bleeding or injury cases. The administration of traditional medication and using tissue are the first aid they could give on the spot. It was as stated by this participant:

"Dealing with the treatment, there were not so many things we could do. It was only just what we could. The problem was we did not know how to engage with it. We only could apply embrocation, dry tissue to clean the blood. That's all. We did not know the others. We could not even apply the tape since we did not have it at home. We just picked what we could take, tissue and the embrocation" (P6).

"When it deals with the head-bleeding, we could only clean it until it dried" (P6).

The utterance shows that the common people picked up anything they could to provide the care. In their daily life, the participants did not provide the basic aid for various emergency conditions such as tools to treat a wound or bleeding. This 
condition made the people tended to treat the wound by using natural medications at home.

An accident is an unpredictable occurrence. It may occur anytime and anywhere. Such a sudden incident when it is found by common people around the accident spot would make the first aid given without sufficient tools. It is stated in this research the common people picked up anything they could to provide the care. In their daily life, the Society did not provide the basic aid for various emergency conditions such as tools to treat a wound or bleeding.

In such a limitation, the first responders attempted to provide the aid that they thought the best for the victims. The aid was done by using natural medicine and the nearest available tools at home. Dealing with a bleeding case, the people would use a dry tissue or fabric. It was used to stop the bleeding and to clean the blood on the victims. Meanwhile, dealing with injured victims, they would be taken care of by applying herbal embrocation on the wound. The given embrocations were such as embrocation oil, baby oil, and massage oil. With such tool limitations, the attempt to provide the first aid was done with the hope to make the patients' conditions better. However, in this case, it was found that all administered aids were without self-protecting tools for the rescuer such as gloves while having direct contact with the victims. It was because gloves were types of tools that generally were not owned by the people.

A previous study conducted in India found $7.6 \%$ of the participants argued to not provide any aid since they did not have anything to administer the first aid (Pallavisarji et al., 2013). Other studies found that besides improving the role of the trained-common people in providing the first aid, an attempt to meet the necessity of the service could be improved by providing first aid kit. It contained several simple tools such as gloves, gauze, bandage, etc. (Jayaraman et al., 2009b).

\section{First Responders Struggled to Help the Victims by sending him off the Nearest Health Service Immediately so they could Gain Proper First Aid.}

When an accident occurred, first responders on the spot would respond to provide the aid. Various aids were given by the first responders on the spot. The most common things conducted by the first responders were sending off the victims to health services so the victims could obtain more professional care. It was stated by this following participant:

"There were some of them having a minor wound. Their bleedings were still leaking. So anything we could pick at that time we took it to stop the bleeding. We called a car and immediately sent him off to the hospital" (P3).

A similar thing was stated by the traffic police officer. It was said that the victims were sent off a health service. It was an immediate decision to do. This decision was taken without providing the basic aid for the victims on the spot as stated by this following participant:

"At that time, what was in our thought was only to send him to the hospital for better medical treatment" (P4). 
The first responders' attempts to immediately send the victims to the health services were done for the sake of the victims' safety. Moreover, when they were in an emergency condition medically as stated by this participant:

"When they were in a very emergency condition, they would be carried because it was for the sake of their safety and survivability" (P8).

Various expressions from the participants, either the people or the traffic police officer, showed that the first responders on the spot struggled to provide care based on what they got. Sending off the victims to the health service became the most common help the first responders could provide on the spot.

While an accident occurred, various conditions might be experienced by the victims. The accident condition would cause mild, moderate, or even severe trauma. In this condition, several participants would provide different attempts of aids on the spot. The most common thing to do by the first responders was taking the victims to a health service. This decision was done to make the victims getting more professional care. Besides that, this decision was taken since there was no pre-hospital service of an emergency state condition that allowed them to provide basic aid by more professional workers.

Sending off the victims to a hospital after an accident would be the most accurate decision on several accidents especially when the victims suffered severe trauma. It made the first responders sending the victims without providing any basic aid on the spot. The first responders attempted to take the victims to a health service for the sake of their safety.

The previous study showed that the research participants identified that promoting immediate transport to a hospital would be the main purpose to do. Professional medical service outside of a hospital in an emergency condition that was not available decided to take the patient to a hospital to be the most appropriate thing to do (Chokotho et al., 2017). Other studies found that immediate and accurate aids and transporting the injured patients to medical centers were considered as the main attempts to do on the response phase. It could avoid any fatal death with a percentage of 39\% before arriving at the hospital (Alinia, Khankeh, Maddah, \& Negarandeh, 2015). Any delay to reach health facilities could worsen the victims' conditions (Jammeh, Sundby, \& Vangen, 2011).

It was as stated by the previous findings that most people wanted to provide the first aid for the trauma victims. They also attempt to save their lives especially when an accident led to serious injuries (Chokotho et al., 2017). Besides that, the common people involved in accident cases were found to have other influential factors. They influenced the arrival and involvement of the common people such as the serious wound of the victims (Hadigal \& Rao, 2011).

\section{First Responders Struggled to Help the Accident Victims by sending them off to the Health Service by Using Public Transportation.}

The first responders on the location sent the victims by picking up any transportation. The most frequently used transportation was the one passing the 
accident spot. Generally, the applied transportation was a pickup car or a private car. It was as stated by the participant as follows:

"Since it could not wait anymore. The victim was immediately sent off to a hospital.

We tried to get a car but we could not until there was a car in a person's house. He saw if there was an accident. We borrowed his car to send the victims to the hospital" (P6).

"Thus, we thought to pick what we could do. Thus, we sent him immediately. The most important was to make him reach the hospital" (P6).

A similar thing was stated by the traffic police officer. It was stated by the accident victims were sent off to health service by using a passing-by vehicle, such as a pickup car as stated below.

"It was so fortunate there was a car passing by. I stood up in front of the care asking for help to send the victims to a health center" (P2).

The statement was expressed by both the people and the traffic police officer. Generally, the transporting process was done by picking up what they could grab on the spot. It was absolutely without discriminating against the conditions of the vehicles for the victims. The reason was they need more supportive medical tools based on the conditions they experienced during being transported to the hospital. It was done by the hope to allow the victims to have the more effective treatment and also to avoid any worsening condition.

In several accident cases, the first responders attempted to send off the victims to an adequate health service. This decision was realized by taking any vehicles to transport on the spot. The transportations were the nearest vehicles on the spot or the stopped vehicles that passed by the traffic accident spot. Generally, the taken transporting vehicles to carry the victims were private vehicles, pickup care, or other motored vehicles.

By taking the nearest transportation to the location, it was assumed to be the easiest solution to do. It was admitted the easiest thing to do rather than going to health service and asked for standardized and safe vehicles such as an ambulance. Besides that, the use of public transportation was considered more efficient in terms of time. It could have been more difficult when a victim suffered severe trauma and required immediate speed to take the victims. They did it although it was realized that the chosen transportation did not have sufficient-basic medical equipment for emergency state condition aids.

The previous findings found $66.1 \%$ of patients were carried by private cars instead of ambulances (Uthkarsh, 2010 in Suryanto, Plummer, \& Boyle, 2017). A study conducted in Tanzania found that in traffic accidents, 35\% of the first responders would use transportations in the form of private cars to send off the victims to a medical facility. It was also found that choosing caps contributed $26 \%$ and taking a taxi bike and bus with a percentage of $6 \%$ (Kuzma, Lim, Kepha, Nalitolela, \& Reynolds, 2015) 


\section{The Police Officers' Support to Find the Accident Victims.}

During the traffic accidents, usually, the traffic police officers would come to the spot after receiving the report. The police officer's arrival is an effort to provide care for the accident victims. Generally, for the first time when an accident occurred, the traffic police officer would secure the accident spot. This is done by the traffic police officer. It has a purpose to avoid further accidents. It was as stated by this informant:

"What we usually do when we arrive is to check the sprawling victim. The first action to do is observing the situation whether it is disturbed or not. We prevent to not allow any further accident" (P5).

The occurring accident on the roads may cause further traffic jams. Such an accident would make may vehicles stopping by either to provide aid or only to see the accidents. It was stated by this participant:

"Since that area was still suburban, so when there was an accident, the people would gather along. Thus, it hindered any vehicles to pass by. Thus, it would be better to send the victims to the hospital directly since when an accident occurred the people would gather there. It made many vehicles stopped there. Thus, when we wanted to carry the victims quickly, it was hindered since we needed to regulate the traffic to make the aid provision quickly administered (P5).

While providing the first aid, before the police officer arrived on the spot, they had struggled to prepare themselves for various conditions. They prepared themselves and equipped with emergency equipment. The preparation was started by preparing all persons in the field. They were well prepared started from the emergency tools for accidents and vehicles. It was as stated by this participant:

At that time, when we received the report from the people or other police officers either directly or via a phone call, the stand-by police officers in Konawe municipality would depart. Before leaving, we prepared all the police officer members. The departed members would be briefed to promote what actions should we do later on the spot. Then, the second preparation is to bring the equipment to process the spot, handle the accident, regulate the traffic. The third one is to prepare the vehicle. It must be in a top condition so it will not hinder our process in providing care for the accident" (P4).

"What we prepare deals with the persons' readiness and the equipment. The equipment consists of Kit to use on the spot. Inside of the Kit, we have a gauge, first aid kit, iodine, cotton, and bandage" (P5).

The traffic police party found a dead victim on the accident spot, then they will administer the first aid. It was stated by the participant:

"When the victims died, were knocked out, we drew their figures and provided financial support. Then, we took their photographs. After that, we brought them to the hospital to undergo post-mortem" (P4),

"When the victims died, we put them into a corpse bag. We put them inside then we took them to the hospital for having post-mortem process" (P4). 
Dealing with mild and severe trauma patients, they would be treated based on what they felt.

"Such an action should be carefully considered. Which part is injured? Is he bleeding and how is it? Then, we provide the first aid and send him to a hospital. In a bleeding case, it should be observed first in which part. When it has been located, that part should be covered" (P5)

"Let me put it this way. Usually, when we are on the spot, we check the victims. If the victims have abraded wound and it is not severe, we will immediately take them" (P4)

The police officers, to support the first aid for the accident victims, were prepared by basic knowledge to deal with the emergency condition of traffic accident victims. This knowledge was obtained during their education or training. The training was given for each resort police in turn. It was expressed by this participant:

"We were indeed prepared with the basic knowledge to treat victims when we had our education. The name was the First Aid for Emergency State Condition. We were taught to treat emergency state condition patients such as traffic accident victims, immediate care, caring fainted victims, and carrying the victim. Those what we learned. Dealing with further care, it would be the responsibility for the concerning party" (P4)

From the statement, they described that the police officers could support the attempt to provide first aid for traffic accident victims. The police officers were already prepared with the basic knowledge concerning the first aid for emergency state cases. The traffic police officers were already prepared with basic knowledge and skill concerning the first aid they got during their education. They also had rescue protocol and were prepared with the required basic tools while providing first aid on the field.

Generally, when an accident occurs, the police officers attempt to secure the accident spot. It is done to see the condition on the field whether the accident occurs on the main road. It usually leads to traffic jam since many vehicles stop. This condition contributed to the process of administering the first aid for the accident victims. Regulating the traffic of the accident spot would support the first aid administration process for the victims.

Besides regulating the traffic, to make the traffic flowed, the police officers also prepared several things before they arrived on the spot. It was done to accelerate the process of helping the victims based on their conditions such as mild injury or even dead victims. To take care of a dead victim, it was done with the police protocol. The victim would be put in a corps bag that they had prepared before being sent off to a hospital for having post-mortem. Before having postmortem, the location identification of the victim was promoted to prepare further investigation. Meanwhile, for mild or severe injured victims, they would be taken care of based on their injuries and the knowledge and skills of the police officers.

In several traffic accidents, usually, the traffic police officers would come to the spot after receiving the report. The police officer's arrival is an effort to provide 
care for the accident victims. They would provide the first aid by promoting their roles in securing the accident spot. It had a purpose to avoid further accidents. A previous study found that the traffic police officers would be on the accident spots after they were called. Their main roles were regulating the traffic flows around the accident spot (deploying the reflective triangle and a flare on the road to slow down the incoming traffic) and to conduct a further investigation with a lawful purpose (Chokotho et al., 2017).

Several accident cases on the main road would cause a further traffic jam. It surely would interrupt the evacuation process of the victims. Such traffic jam occurred due to the volume of vehicles that stopped by on the spot. Therefore, traffic regulation management on the spot was required to support the first aid administration process for the victims. Other studies found that traffic jams occurred due to common people around the spot. It could influence the aid administration process. Sometimes, the traffic jams due to common people on the spot could lead to further accidents for them who stopped and looked at the accident on the spot (Khorasani-Zavareh et al., 2009).

\section{CONCLUSION}

First responders would struggle to provide the first aid when they faced an accident case. There were several actions they did while they were on the spot. They struggled to save traffic accident victims after the incident. They helped accident victims with limited tools. They helped the accident victims by sending them off to a health service immediately. They attempted to help the victims by sending them off to health service by using public transportation.

It could be concluded that in the area that has not applied integratedemergency pre-hospital service, it would directly influence service availability in society. The people would struggle to substitute the roles of medical workers in administering the first aid outside of a hospital with various limitations. Education and training programs concerning administering first aid, given quarterly, could be an appropriate health service program to offer for broader people as the first responders.

\section{REFERENCES}

1. Alinia, S., Khankeh, H., Maddah, S. S. B., \& Negarandeh, R. (2015). Barriers of pre-hospital services in road traffic injuries in Tehran: the viewpoint of service providers. International journal of community based nursing and midwifery, 3(4), 272.

2. Balikuddembe, J. K., Ardalan, A., Khorasani, D., Nejati, A., \& Raza, O. (2017). Weaknesses and capacities affecting the Prehospital emergency care for victims of road traffic incidents in the greater Kampala metropolitan area: a crosssectional study. BMC emergency medicine, 17(1), 29.

3. Beuran, M., Paun, S., Gaspar, B., Vartic, M., Hostiuc, S., Chiotoroiu, A., \& Negoi, I. (2012). Prehospital trauma care: a clinical review. Chirurgia, 107, 564-570. 
4. Chokotho, L., Mulwafu, W., Singini, I., Njalale, Y., Maliwichi-Senganimalunje, L., \& Jacobsen, K. H. (2017). First responders and prehospital care for road traffic injuries in Malawi. Prehospital and disaster medicine, 32(1), 14-19.

5. Debenham, S., Fuller, M., Stewart, M., \& Price, R. R. (2017). Where there is no EMS: lay providers in Emergency Medical Services care-EMS as a public health priority. Prehospital and disaster medicine, 32(6), 593-595.

6. Elmqvist, C., Brunt, D., Fridlund, B., \& Ekebergh, M. (2010). Being first on the scene of an accident-experiences of 'doing'prehospital emergency care. Scandinavian Journal of Caring Sciences, 24(2), 266-273.

7. Goonewardene, S. S., Baloch, K., Porter, K., Sargeant, I., \& Punchihewa, G. (2010). Road Traffic Collisions-Case Fatality Rate, Crash Injury Rate, and Number of Motor Vehicles: Time Trends Between a Developed and Developing Country. The American Surgeon, 76(9), 977-981.

8. Hadigal, S., \& Rao, G. V. R. (2011). Study of mob-behavior during road traffic accidents in Hyderabad. Transforming Emergency Management, 8.

9. Husum, H., Gilbert, M., Wisborg, T., Van Heng, Y., \& Murad, M. (2003). Rural prehospital trauma systems improve trauma outcome in low-income countries: a prospective study from North Iraq and Cambodia. Journal of Trauma and Acute Care Surgery, 54(6), 1188-1196.

10. Jammeh, A., Sundby, J., \& Vangen, S. (2011). Barriers to emergency obstetric care services in perinatal deaths in rural gambia: a qualitative in-depth interview study. ISRN obstetrics and gynecology, 2011.

11. Jayaraman, S., Mabweijano, J. R., Lipnick, M. S., Caldwell, N., Miyamoto, J., Wangoda, R., . . O Ozgediz, D. (2009a). Current patterns of prehospital trauma care in Kampala, Uganda and the feasibility of a lay-first-responder training program. World journal of surgery, 33(12), 2512-2521.

12. Jayaraman, S., Mabweijano, J. R., Lipnick, M. S., Caldwell, N., Miyamoto, J., Wangoda, R., . . . Ozgediz, D. (2009b). First things first: effectiveness and scalability of a basic prehospital trauma care program for lay first-responders in Kampala, Uganda. PLoS One, 4(9).

13. Khorasani-Zavareh, D., Khankeh, H. R., Mohammadi, R., Laflamme, L., Bikmoradi, A., \& Haglund, B. J. (2009). Post-crash management of road traffic injury victims in Iran. Stakeholders' views on current barriers and potential facilitators. BMC emergency medicine, 9(1), 8.

14. Kironji, A. G., Hodkinson, P., De Ramirez, S.S., Anest, T., Wallis, L., Razzak, J., . .. Hansoti, B. (2018). Identifying barriers for out of hospital emergency care in low and low-middle income countries: a systematic review. BMC health services research, 18(1), 291.

15. Kuzma, Kristin, Lim, Andrew George, Kepha, Bernard, Nalitolela, Neema Evelyne, \& Reynolds, Teri A. (2015). The Tanzanian trauma patients' prehospital experience: a qualitative interview-based study. BMJ open, 5(4), e006921.

16. Mock, C. N., Jurkovich, G. J., Arreola-Risa, C., \& Maier, R. V. (1998). Trauma mortality patterns in three nations at different economic levels: implications for 
global trauma system development. Journal of Trauma and Acute Care Surgery, 44(5), 804-814.

17. Mock, C. N., Tiska, M., Adu-Ampofo, M., \& Boakye, G. (2002). Improvements in prehospital trauma care in an African country with no formal emergency medical services. Journal of Trauma and Acute Care Surgery, 53(1), 90-97.

18. Novitaria, W., Wigati, P. A., \& Sriatmi, A. (2017). Analisis Kesiapan Pelaksanaan Sosialisasi Program Ambulance Hebat Dalam Rangka Dukungan Terhadap Sistem Penanggulangan Gawat Darurat Terpadu Di Kota Semarang. Jurnal Kesehatan Masyarakat (e-Journal), 5(4), 164-171.

19. Pallavisarji, U., Gururaj, G., \& Girish, R. N. (2013). Practice and perception of first aid among lay first responders in a southern district of India. Archives of trauma research, 1(4), 155.

20. Pigoga, J. L., Cunningham, C., Kafwamfwa, M., \& Wallis, L. A. (2017). Adapting the emergency first aid responder course for Zambia through curriculum mapping and blueprinting. BMJ open, 7(12), e018389.

21. Polri, K. (2018). Jumlah Kecelakaan Lalulintas. Indonesia: Korps Lalulintas Kepolisian Negara Republik Indonesia.

22. Suryanto, Plummer, V., \& Boyle, M. (2017). EMS systems in lower-middle income countries: a literature review. Prehospital and disaster medicine, 32(1), 64.

23. Uthkarsh, P. S. (2010). Study of gaps between precepts and practices in prevention of injuries and prehospital care among injury cases admitted to MSRMC Bangalore, Karnataka, India. Injury prevention, 16(Suppl 1), A195-A195.

24. Wesson, H. K. H., Boikhutso, N., Bachani, A. M., Hofman, K. J., \& Hyder, A. A. (2014). The cost of injury and trauma care in low-and middle-income countries: a review of economic evidence. Health policy and planning, 29(6), 795-808.

25. Wesson, H. K. H., \& Kwong, M. (2017). Trauma care in India: A review of the literature. Surgery, 162(6), S85-S106. 